\title{
Effect of Biostimulation Using Sewage Sludge, Soybean Meal, and Wheat Straw on Oil Degradation and Bacterial Community Composition in a Contaminated Desert Soil
}

\author{
Sumaiya Al-Kindi* and Raeid M. M. Abed* \\ Biology Department, College of Science, Sultan Qaboos University, Muscat, Oman
}

\section{OPEN ACCESS}

Edited by:

Wael Ahmed Ismail,

Arabian Gulf University, Bahrain

Reviewed by:

Dayananda Chandrappa,

University of Exeter, UK

Magdy El-Said Mohamed,

Saudi Aramco, Saudi Arabia

Michel C. Boufadel,

New Jersey Institute of Technology,

USA

*Correspondence:

Raeid M. M. Abed

rabed@mpi-bremen.de;

Sumaiya Al-Kindi

alkindi33@gmail.com

Specialty section:

This article was submitted to Microbiotechnology, Ecotoxicology

and Bioremediation,

a section of the journal

Frontiers in Microbiology

Received: 18 October 2015

Accepted: 15 February 2016

Published: 04 March 2016

Citation:

Al-Kindi S and Abed RMM (2016)

Effect of Biostimulation Using Sewage

Sludge, Soybean Meal, and Wheat

Straw on Oil Degradation

and Bacterial Community

Composition in a Contaminated

Desert Soil. Front. Microbiol. 7:240.

doi: 10.3389/fmicb.2016.00240
Waste materials have a strong potential in the bioremediation of oil-contaminated sites, because of their richness in nutrients and their economical feasibility. We used sewage sludge, soybean meal, and wheat straw to biostimulate oil degradation in a heavily contaminated desert soil. While oil degradation was assessed by following the produced $\mathrm{CO}_{2}$ and by using gas chromatography-mass spectrometry (GC-MS), shifts in bacterial community composition were monitored using illumina MiSeq. The addition of sewage sludge and wheat straw to the desert soil stimulated the respiration activities to reach 3.2-3.4 times higher than in the untreated soil, whereas the addition of soybean meal resulted in an insignificant change in the produced $\mathrm{CO}_{2}$, given the high respiration activities of the soybean meal alone. GC-MS analysis revealed that the addition of sewage sludge and wheat straw resulted in 1.7-1.8 fold increase in the degraded $\mathrm{C}_{14}$ to $\mathrm{C}_{30}$ alkanes, compared to only 1.3 fold increase in the case of soybean meal addition. The degradation of $\geq 90 \%$ of the $C_{14}$ to $C_{30}$ alkanes was measured in the soils treated with sewage sludge and wheat straw. MiSeq sequencing revealed that the majority (76.5-86.4\% of total sequences) of acquired sequences from the untreated soil belonged to Alphaproteobacteria, Gammaproteobacteria, and Firmicutes. Multivariate analysis of operational taxonomic units placed the bacterial communities of the soils after the treatments in separate clusters (ANOSIM $R=0.66, P=0.0001$ ). The most remarkable shift in bacterial communities was in the wheat straw treatment, where 95$98 \%$ of the total sequences were affiliated to Bacilli. We conclude that sewage sludge and wheat straw are useful biostimulating agents for the cleanup of oil-contaminated desert soils.

Keywords: desert soil, oil, illumina, bioremediation, sewage sludge, soybean meal, wheat straw

\section{INTRODUCTION}

Oil contamination results in a dramatic increase in carbon sources in affected soils and a depletion of important nutrients such as nitrogen and phosphorus (Boufadel et al., 1999; Hazen, 2010). This imbalance in carbon-nitrogen ratio and the nitrogen deficiency hamper the biodegradation process (Chorom et al., 2010). Waste materials, such as sewage sludge and soybean meal (termed 
hereafter as SG and SB, respectively), are potential stimulating agents for bioremediation as they are economically feasible and rich in nutrients such as phosphorus, nitrogen and carbon (Cui et al., 2008; Agamuthu et al., 2013). SG has been used as an organic fertilizer, a soil ventilator and a bioaugmentation agent in the bioremediation of oil- and metal-contaminated soils (Gallego et al., 2001; Hamdi et al., 2006; Chorom and Hosseini, 2011; Park et al., 2011). The addition of SG reduced up to $45 \%$ of polyaromatic hydrocarbons (PAHs) and 43$98 \%$ of total petroleum hydrocarbons (TPHs) in different contaminated soils (Hur and Park, 2003; Chorom et al., 2010; Ros et al., 2010; Zhang et al., 2012). SB has also been used as a source of organic nitrogen in the bioremediation of several oil-contaminated soils (Diab, 2013). The addition of SB has been shown to enhance biosurfactant production and to increase hydrocarbons bioavailability (Diab and Sandouka, 2012).

Besides nutrients, oxygen is another limiting factor that influences the efficiency of bioremediation processes especially that the first step in the breakdown of hydrocarbons under aerobic conditions relies on oxygen-dependent enzymes (Gallego et al., 2001). Different aeration methods, such as titling, forced aeration and addition of bulking agents, were employed to accelerate bioremediation (Rhykerd et al., 1999; Odokuma and Dickson, 2003; Marin et al., 2006; Hu et al., 2012). The function of bulking agents is to increase soil porosity, increase oxygen diffusion, lower soil's bulk density and provides a valuable carbon and energy source for microorganisms (Rhykerd et al., 1999; Lang et al., 2000; Huang et al., 2006). Wheat straw (termed hereafter as WS), wood chips, post-peelings, peanut powder were successfully used as aerating agents to biostimulate the growth and activity of microorganisms in PAH-contaminated soils (Llado et al., 2015).

The bioremediation of desert soils is challenging, mainly because of the harsh environmental conditions. The diversity of microorganisms in oil-contaminated arid deserts and their response to different bioremediation treatments have been relatively much less studied than marine sediments. In the Arabian Peninsula, oil spills are very common in deserts, nevertheless little research has been performed to study their environmental impacts and remediation (Radwan, 2008, 2009). Here, we investigate the effect of the biostimulators SG, SB, and WS on respiration activities, hydrocarbons degradation and bacterial community changes in oil-contaminated soils from the desert of Oman. To the best of our knowledge, the response of bacterial activity and diversity in oil-contaminated desert soils to three biostimulating agents has been rarely compared in a single study and using next generation high throughput sequencing (NGS). Recently, NGS has become a robust and a straightforward technology with the ability to generate large sequence databases in a massively parallel fashion (Shokralla et al., 2012). This technique has yielded comprehensive information on the structure of microbial communities and their shifts in contaminated sites (Singleton et al., 2013; Lamendekka et al., 2014; Sun et al., 2015).

\section{MATERIALS AND METHODS}

\section{Collection of Soils and Organic Wastes}

Oil-contaminated soils were collected on May, 2013 from a dumping area in the deserts of Marmul, Southwest of Muscat, Sultanate of Oman (lat. $18^{\circ} 10^{\prime} 01.3^{\prime \prime} \mathrm{N}$; long. $55^{\circ} 14^{\prime} 32.9^{\prime \prime} \mathrm{E}$ ). The area is located close to an oil exploration field and used to collect the oil-contaminated soils, so crude oil was the sole contaminant in the region. Approximately $500 \mathrm{~g}$ of the top $1 \mathrm{~cm}$ of the soils were collected in triplicates from three locations that were 50$100 \mathrm{~m}$ apart. TPH in the soils were gravimetrically measured after extraction of $5 \mathrm{~g}$ of soil using $15 \mathrm{ml}$ of dichloromethane (DCM, Sigma-Aldrich, Germany) for 2-3 times. The extracts were filtered by non-absorbent cotton and then subjected to evaporation by rotary evaporator to quantify TPH (Weisman, 1998). The $\mathrm{pH}$ and electrical conductivity (EC) were measured using the filtrates of $10 \mathrm{~g}$ soil mixed with $50 \mathrm{ml}$ of deionized water, using calibrated YSI instruments. Anions were extracted and evaluated using ion chromatography (IC, Metrohm AG, Herisau, Switzerland). The percent of sand, silt and clay in the soil was determined by a standard hydrometer method (Klute, 1986), and this percent was used to categorize the soil texture from a soil triangle (Brady, 1984).

SB and WS were collected from the Gulf Mushroom Products Company (S.A.O.G) in Barka, Oman. The average moisture and nitrogen contents of the SB were 10 and $8 \%$, whereas these values were 12 and $0.5 \%$ for the WS, respectively. SG was collected from an aeration tank in the wastewater treatment plant at Sultan Qaboos University (SQU).

\section{Biostimulation Experiment in Glass Bottles}

Biostimulation experiments were conducted in closed glass bottles (termed hereafter as bottle experiment) in order to follow respiration activities of untreated and treated soils through measuring the amount of produced $\mathrm{CO}_{2}$ and to measure oil degradation at the end of the treatments using gas chromatography-mass spectrometry (GC-MS). One gram of oilcontaminated soil was placed in $165 \mathrm{ml}$ serum glass bottles. To this, $50 \mathrm{mg}$ of each of the biostimulating agents (i.e., SG, $\mathrm{SB}$, and WS) were added. Five $\mathrm{ml}$ of sterilized water were added to each vial. Two controls were maintained; one with contaminated soil but without any treatment (untreated soil) and the other with only the biostimulating agent without soil. All treatments and controls were maintained in triplicates. All vials were sealed with a butyl rubber stopper and an aluminum crimp cap to ensure no gas leakage and were incubated for 110 days in the oven at $30^{\circ} \mathrm{C}$ without shaking. The produced $\mathrm{CO}_{2}$ was measured by withdrawing $250 \mu \mathrm{l}$ from the headspace of the bottle using a gas-tight glass syringe and injecting manually into gas chromatography (GC, Agilent model 6890N). The GC was equipped with a thermal conductivity detector and a $30 \mathrm{~m} \times 250 \mu \mathrm{m}$ capillary column (HP-PLOT Q). Helium was used as a carrier gas at a flow rate of $4 \mathrm{ml} \mathrm{min}^{-1}$ and the injector and detector temperatures were maintained at 200 and $210^{\circ} \mathrm{C}$, respectively. The oven temperature was programmed from 50 to $80^{\circ} \mathrm{C}$ (final hold time $3 \mathrm{~min}$ ) at a rate of $20^{\circ} \mathrm{C} \mathrm{min}^{-1}$. 
Carbon dioxide $\left(\mathrm{CO}_{2}\right)$ evolution data were statistically analyzed by one-way ANOVA using the SPSS software (10th edition, Chicago, IL, USA). $P$-values were adjusted using the sequential Bonferroni (Quinn and Keough, 2002) and Tukey's test was used to determine differences between individual means. The degradation of the oil in the bottle experiment was assessed using GC-MS analysis of the alkanes (see below). The ratios of degraded alkanes to the amount of produced $\mathrm{CO}_{2}$ in the SG and WS treated soils were calculated, after subtracting the $\mathrm{CO}_{2}$ produced from soil-free SG and WS.

\section{Biostimulation Experiment in Microcosms}

Since the laboratory experiment was performed in closed bottles to enable the measurement of $\mathrm{CO}_{2}$ gas in the headspace, oxygen could become limited and this could slow down biodegradation processes. Therefore, another experiment was performed in open-air glass aquaria (termed hereafter as microcosm experiment) in order to follow the degradation using GC-MS and to monitor shifts in the bacterial community structure. Here, $100 \mathrm{~g}$ of soil were placed in glass aquaria $(15 \mathrm{~cm}$ diameter). Five grams of each of the biostimulating agents (i.e., SG, SB, and WS) were added individually to each aquarium. Untreated soils were kept as controls. All treatments and controls were maintained in triplicates. The biostimulating agents were mixed with the soil, and the mixture was tilled twice a week using a sterile spatula. The mixture was always kept wet by adding $10 \mathrm{ml}$ of sterile water every 2 days. All incubations were kept for 64 days at ca. $30 \pm 3^{\circ} \mathrm{C}$ in a greenhouse. Samples (i.e., $1 \mathrm{~g}$ soil each) were collected for GC-MS analysis and MiSeq illumina (see below).

Oil biodegradation (mainly $C_{11}$ to $C_{30}$ alkanes) from the microcosm experiments (and from the bottle experiments) was followed using GC-MS analysis of the soils at the end of the experiment. One gram of each soil was extracted three times in $5 \mathrm{ml}$ dichloromethane (DCM, Sigma-Aldrich, Germany) and then sonicated for $25 \mathrm{~min}$ at $10^{\circ} \mathrm{C}$. The extracted supernatant was mixed with sodium sulfate and was filtered with non-absorbent cotton to remove solid particles. The filtrate was then evaporated using a rotary evaporator. The dry extract was re-dissolved into DCM and passed through silica gel prior to injection into GC-MS (Perkin Elmer Clarus 600GC/MS). The Perkin Elmer Clarus 600C MS was coupled with $\mathrm{Rtx}^{\circledR}-5 \mathrm{MS}$ capillary column $(30 \mathrm{~m} \times 0.25 \mathrm{~mm}$ I.D. $\times 0.25 \mu \mathrm{m}$ film thickness; maximum temperature, $350^{\circ} \mathrm{C}$ ). Ultra-high purity helium was used as a carrier gas at a constant flow of $1.0 \mathrm{ml} / \mathrm{min}$. The ionizing energy was $70 \mathrm{eV}$. Electron multiplier (EM) voltage was obtained from autotune. The injection, transfer line and ion source temperatures were 290,280 , and $280^{\circ} \mathrm{C}$, respectively. The oven temperature program was held at $80^{\circ} \mathrm{C}$ for $5 \mathrm{~min}$ and then accelerated at a rate of $10^{\circ} \mathrm{C} / \mathrm{min}$ to $280^{\circ} \mathrm{C}$ (hold for $30 \mathrm{~min}$ ). The volume of injected sample was $1 \mu \mathrm{l}$ with a split ratio of 10:1. The standard mix solution $\left(C_{7}\right.$ to $\left.C_{30}\right)$ of concentrations $10,20,30,40$, and 50 ppm were used for confirmation and quantification purposes. A calibration curve conformed by the standard mixtures was established and quantification of the analyzed compounds was performed in the linear range of the calibration curve. The alkanes were identified based on GC retention times of the standard, injected and analyzed under the same conditions as samples and by comparing the spectra obtained with mass spectrum libraries (NIST 2011 v.2.3 and Wiley, 9th edition).

\section{Bacterial Community Analysis using Illumina}

DNA was extracted from the soils at the end of the microcosm experiment using skim milk protocol (Volossiouk et al., 1995). Purified DNA extracts were then submitted to Molecular Research MR DNA laboratory (www.mrdnalab.com, Shallowater, TX, USA) for illumina MiSeq sequencing of the bacterial $16 \mathrm{~S}$ rRNA genes using the primers $341 \mathrm{~F}\left(5^{\prime}\right.$-CCT ACGGGNGGCWGCAG-3') and 805R (5'-GACTACHVGGG TATCTAATCC- $3^{\prime}$ ) with barcode on the forward primer (Klindworth et al., 2013). After amplification, PCR products were checked in $2 \%$ agarose gel to determine the success of amplification and the relative intensity of bands. Multiple samples were pooled together in equal proportions based on their molecular weight and DNA concentrations. Pooled samples were purified using calibrated AMPure XP beads. Then, the pooled and purified PCR products were used to prepare a DNA library by following illumina TruSeq DNA library preparation protocol. Sequence analysis was carried out using the Mothur MiSeq SOP pipeline (Schloss et al., 2009). Briefly, barcodes were removed and sequences $<200$ bp and sequences with ambiguous base calls were eliminated. Sequences were denoised, operational taxonomic units (OTUs) generated and chimeras removed. OTUs were defined by clustering at 3\% divergence (97\% similarity). Final OTUs were taxonomically classified using BLASTn against a curated GreenGenes database (De Santis et al., 2006). Rarefaction curves and diversity indices (OTU richness, Chao-1, and ACE) were calculated using the Mothur software. A multivariate analysis of all samples was performed to examine for significant changes in soil communities after biostimulation treatments using non-metric multidimensional scaling (NMDS) based on Bray-Curtis dissimilarities as described in Ramette and Tiedje (2007). Analysis of similarities (ANOSIMs) was carried out to test for significant differences in bacterial communities. ANOSIM produces a sample statistic $(R)$, which represents the degree of separation between test groups (Clarke, 1993).

\section{RESULTS}

\section{Physicochemical Characteristics of the Desert Soil}

The TPH content in the studied soil was $41.71 \mathrm{mg} \mathrm{g}^{-1}$ soil (Table 1). The soil had a neutral $\mathrm{pH}$. Soil texture was classified as silt loam as it contains more silt than sand and clay. The concentrations of nitrate and phosphate were 0.04 and $0.16 \mathrm{mg} \mathrm{g}^{-1}$ soil, respectively (Table 1). Chloride, bromide, fluoride, and sulfate were measured at detectable amounts (Table 1). This desert soil contained no or very little amounts of biogenic matter. 


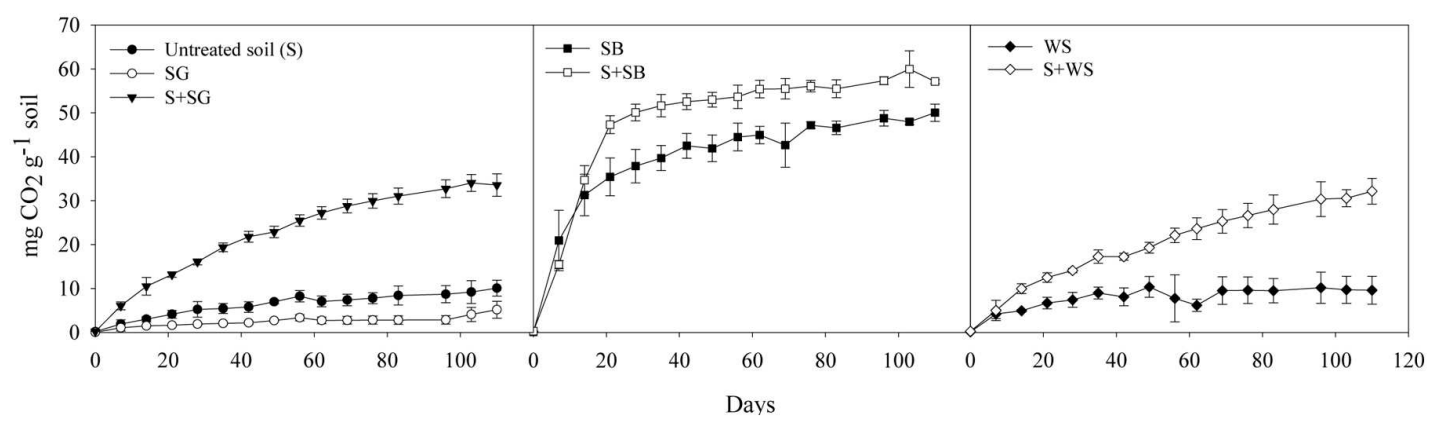

FIGURE 1 | The cumulative amount of $\mathrm{CO}_{2}$ (in $\mathrm{mg} \mathrm{g}^{-1}$ soil) produced from the untreated and the biostimulated soils. Note that the produced $\mathrm{CO}_{2}$ from the soybean alone (SB) was much higher than from the sewage sludge (SG) alone and the wheat straw (WS) alone. Error bars represent \pm standard deviation $(n=3)$.

\section{Changes in Respiration Activities}

The produced $\mathrm{CO}_{2}$ in the untreated desert soil without any amendment reached $10.1 \pm 1.8 \mathrm{mg} \mathrm{CO}_{2} \mathrm{~g}^{-1}$ soil after 110 days of incubation (Figure 1; Table 2). While the SG and the WS alone produced $\mathrm{CO}_{2}$ amounts lower than $10 \mathrm{mg} \mathrm{CO}_{2} \mathrm{~g}^{-1}$ soil,

TABLE 1 | Physicochemical properties of the studied oil-contaminated desert soil.

\begin{tabular}{|c|c|c|c|}
\hline & & Unit & Desert soil \\
\hline \multicolumn{4}{|c|}{ Parameters } \\
\hline $\mathrm{TPH}$ & & $\mathrm{mg} \mathrm{g}^{-1}$ & 41.71 \\
\hline $\mathrm{pH}$ & & & 7.50 \\
\hline EC & & $\mathrm{mS} \mathrm{g}^{-1}$ & 1.52 \\
\hline Fluoride & & $\mathrm{mg} \mathrm{g}^{-1}$ & 0.03 \\
\hline Chloride & & $\mathrm{mg} \mathrm{g}^{-1}$ & 32.52 \\
\hline Bromide & & $\mathrm{mg} \mathrm{g}^{-1}$ & 0.15 \\
\hline Nitrate & & $\mathrm{mg} \mathrm{g}^{-1}$ & 0.04 \\
\hline Phosphate & & $\mathrm{mg} \mathrm{g}^{-1}$ & 0.16 \\
\hline Sulfate & & $\mathrm{mg} \mathrm{g}^{-1}$ & 31.83 \\
\hline \multicolumn{4}{|c|}{ Soil texture } \\
\hline & Sand & $\%$ & 27.00 \\
\hline & Clay & $\%$ & 23.00 \\
\hline & Silt & $\%$ & 50.00 \\
\hline & Type & & Silt loam \\
\hline
\end{tabular}

TPH, Total petroleum hydrocarbons; EC, electrical conductivity at $20^{\circ} \mathrm{C}$. the SB alone yielded a total amount of $50.0 \pm 1.9 \mathrm{mg} \mathrm{CO}_{2} \mathrm{~g}^{-1}$ soil (Figure 1). The addition of SG and WS to the desert soil significantly $(P<0.001)$ stimulated the respiration activities to reach the values $33.6 \pm 2.5$ and $32.1 \pm 2.9 \mathrm{mg} \mathrm{CO}_{2} \mathrm{~g}^{-1}$ treated soil at the end of the incubation period, respectively (Table 2; Figure 1). In the case of $\mathrm{SB}$, the produced $\mathrm{CO}_{2}$ of the treated soil displayed the highest value of $57.1 \pm 0.5 \mathrm{mg}$ $\mathrm{CO}_{2} \mathrm{~g}^{-1}$ soil, however, this value accounts for an insignificant $(P>0.05)$ increase in $\mathrm{CO}_{2}$ from the untreated soil, given the high respiration activities of the $\mathrm{SB}$ alone.

\section{Oil Degradation as Revealed by GC-MS}

In the bottle experiment, GC-MS revealed that around $10.9 \pm 0.1 \mathrm{mg}$ of the $\mathrm{C}_{14}$ to $\mathrm{C}_{30}$ alkanes $\mathrm{g}^{-1}$ soil were degraded in the untreated soil after 110 days of incubation (Table 2; Figure 2). The lighter fraction of alkanes $\left(<\mathrm{C}_{14}\right)$ completely disappeared from the GC chromatograms (Appendix Figure A1). The addition of SG and WS resulted in the degradation of 18.3$19.0 \mathrm{mg}$ of the alkanes $\mathrm{g}^{-1}$ soil at the end of the experiment. These values correspond to the degradation of $>90 \%$ of the total alkanes at a degradation rate of $0.28-0.29 \mathrm{mg}$ of the alkanes $\mathrm{g}^{-1}$ soil day ${ }^{-1}$. The addition of $\mathrm{SB}$ resulted in the degradation of $14.3 \pm 0.4 \mathrm{mg} \mathrm{g}^{-1}$ of the alkanes in 110 days (Table 2; Figure 1). The degradation of $\mathrm{C}_{14}$ to $\mathrm{C}_{30}$ alkanes in the microcosm experiment exhibited a similar pattern to that of the bottle experiment. The maximum amount of alkane degradation

TABLE 2 | The total produced $\mathrm{CO}_{2}$ after 110 days of incubation (without any subtraction) and the amount of degraded alkanes $\left(\mathrm{C}_{14}\right.$ to $\mathrm{C}_{30}$ ) in the bottle

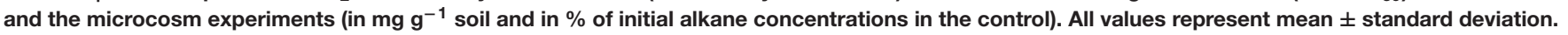

\begin{tabular}{|c|c|c|c|c|c|}
\hline \multirow[t]{3}{*}{ Type of treatment } & \multirow{3}{*}{$\begin{array}{c}\text { Total evolved } \mathrm{CO}_{2} \text { after } \\
110 \text { days }\left(\mathrm{mg}-\mathrm{CO}_{2} \mathrm{~g}^{-1} \text { soil) }\right.\end{array}$} & \multicolumn{4}{|c|}{ Alkane $\left(\mathrm{Ci}_{4}\right.$ to $\left.\mathrm{C}_{30}\right)$ degradation as measured by GC-MS } \\
\hline & & \multicolumn{2}{|c|}{ Bottle experiment (110 days) } & \multicolumn{2}{|c|}{ Mcrocosom experiment (64 days) } \\
\hline & & $\left(\mathrm{mg} \mathrm{g}^{-1}\right)$ & (\%) & $\left(\mathrm{mg} \mathrm{g}^{-1}\right)$ & $(\%)$ \\
\hline Untreated soil (S) & $10.1 \pm 1.8$ & $10.9 \pm 0.1$ & $55 \pm 0.5$ & $9.7 \pm 0.6$ & $50 \pm 3.0$ \\
\hline$S+S G$ & $33.6 \pm 2.5$ & $19.0 \pm 0.7$ & $95 \pm 3.5$ & $18.3 \pm 0.7$ & $92 \pm 3.5$ \\
\hline $\mathrm{S}+\mathrm{SB}$ & $57.1 \pm 0.5$ & $14.3 \pm 0.4$ & $72 \pm 2.0$ & $12.4 \pm 0.5$ & $63 \pm 2.5$ \\
\hline$S+W S$ & $32.1 \pm 2.9$ & $18.3 \pm 0.6$ & $92 \pm 3.0$ & $17.9 \pm 0.1$ & $90 \pm 0.5$ \\
\hline
\end{tabular}

SG, Sludge; SB, soybean meal; WS, wheat straw. 


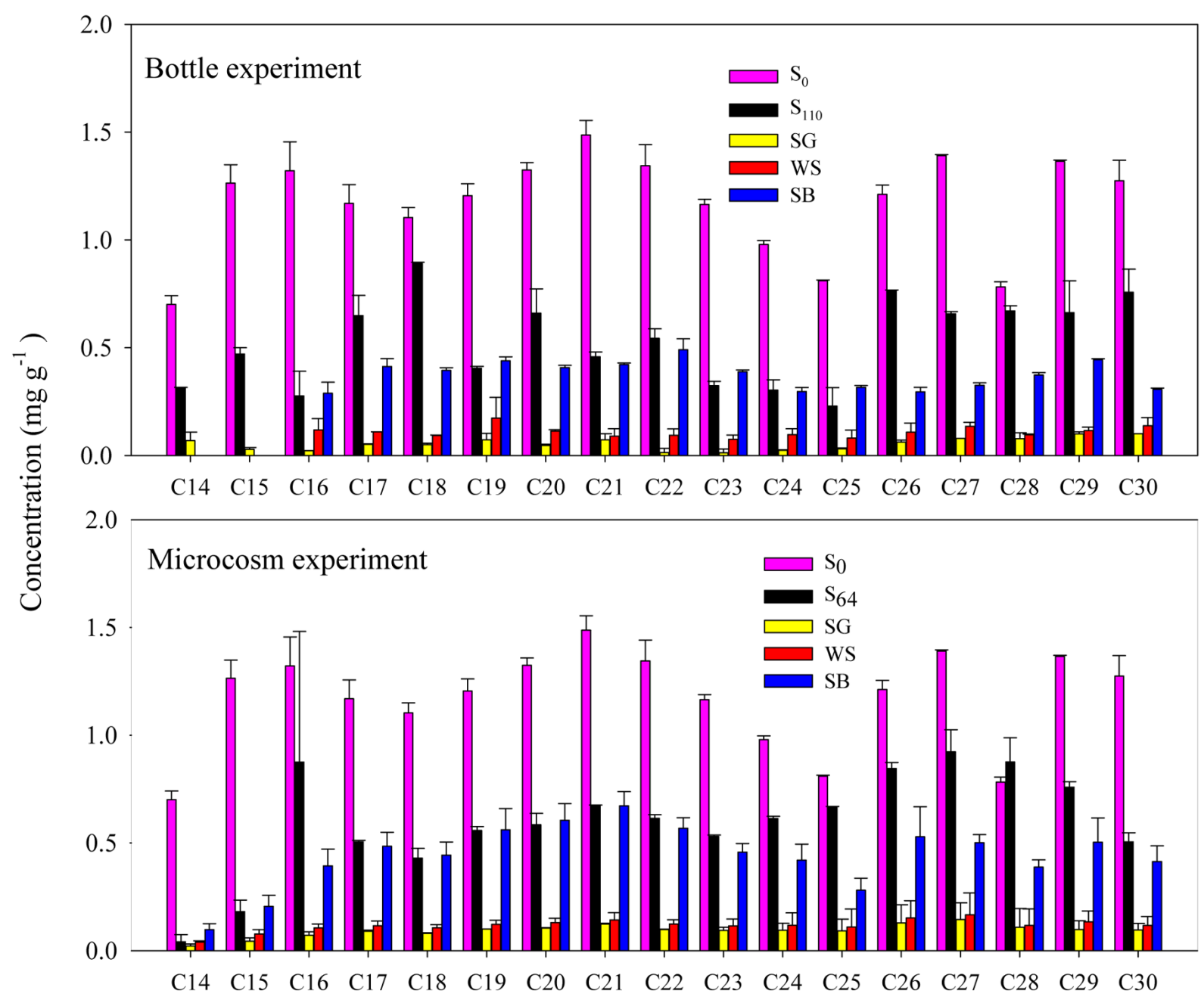

Alkanes

FIGURE 2 | Concentration of individual alkanes $\left(\mathrm{C}_{14}\right.$ to $\left.\mathrm{C}_{30}\right)$ before and after biostimulation with sewage sludge (SG), soybean meal (SB), and wheat straw (WS) in the bottle and the microcosm experiments. Error bars represent \pm standard deviation $(n=3)$.

was $18.3 \pm 0.7 \mathrm{mg} \mathrm{g}^{-1}$ soil after 64 days of treatment with SG (Table 2). This amount corresponds to a degradation rate of $0.29 \mathrm{mg}$ of the alkanes $\mathrm{g}^{-1}$ soil day ${ }^{-1}$.

\section{Bacterial Community Changes}

The total number of generated 16S rRNA gene sequences by illumina MiSeq was 1,395,417 reads. The lowest number of sequences per sample was 27585 and the highest was 295156 (Table 3). Rarefaction curves showed that no samples, regardless of the number of sequences, reached a maximum yield of OTUs (Figure 3A). The number of OTUs, calculated using subsets with the same number of sequences for all samples, was in the range of 240-400 OTUs in the untreated soil (Table 3; Figure 3A). The OTU richness decreased in the untreated soil at the end of the experiment after 64 days of incubation to reach 176-266 OTUs (Figure 3B). In the treated soils, the number of OTUs was lowest in the case of the SG with an average of $199 \pm 6$, whereas the average reached $252 \pm 6$ and $249 \pm 12$ in the case of the SB and the WS, respectively (Figure 3B). When variations in bacterial community composition were visualized in a two-dimensional space using multivariate analyses of OTUs (Figure 3C), the bacterial communities of the triplicates of each treatment were placed in separate clusters (Figure 3C, ANOSIM $R=0.66, P=0.0001)$.

MiSeq data showed noticeable changes in bacterial community composition after 64 days of incubation, both in the treated and untreated soils. At the beginning of the experiment, the original soil was dominated by sequences related to the bacterial groups Alphaproteobacteria, Gammaproteobacteria, and Firmicutes (76.5-86.4\% of total sequences; Figure 4). Sequences belonging to Planctomycetes constituted $15 \%$ of the total number of sequences in one of the replica, but $<2 \%$ in the other two (Figure 4). After 64 days of incubation, the relative abundance of Alphaproteobacteria exhibited a decrease only in 

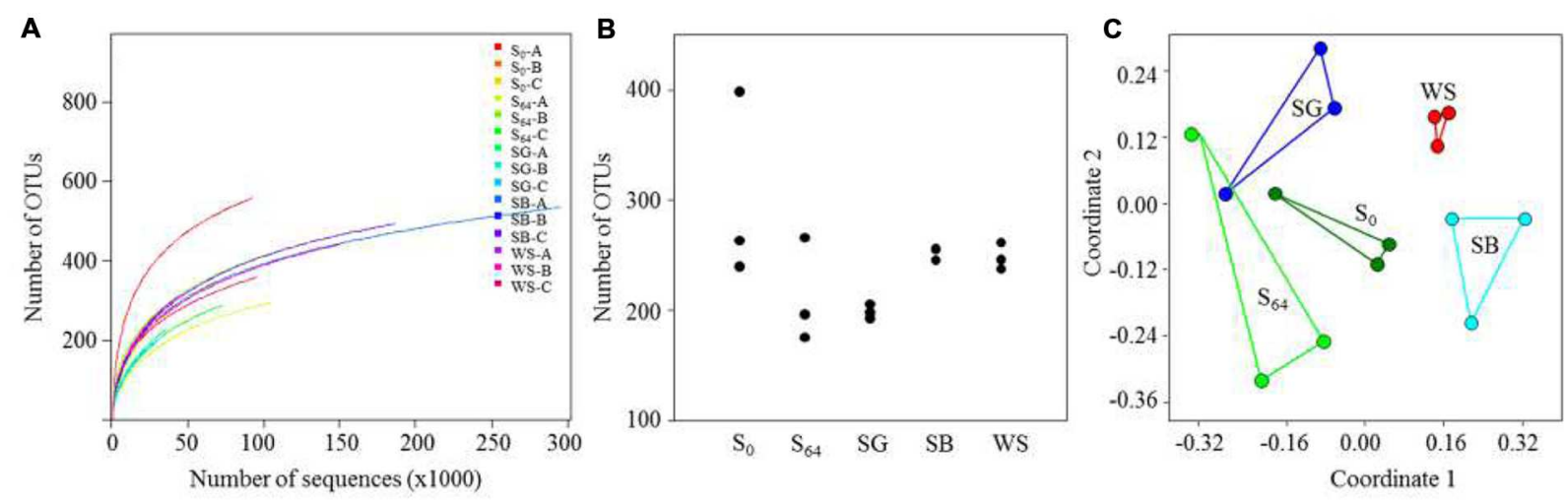

FIGURE 3 | (A) Calculated rarefaction curves of observed OTU (sequences that have 97\% similarity are defined as one OTU) richness in the soils; (B) number of OTUs calculated for the triplicates of each soil sample, using the same number of sequences for all soils; (C) non-metric multidimensional scaling (NMDS) ordination (based on a Bray-Curtis distance matrix) of the triplicates of each treatment.

two replicates to reach $0.6-1.9 \%$ of total sequences (Figure 4 ). The bacterial community also showed a decrease in the relative abundance of Gammaproteobacteria from $13-48$ to $3-20 \%$ of total sequences in all replicates (Figure 4). On the other hand, the relative abundance of Firmicutes increased to $46.6-57.8 \%$ of total sequences at least in two replicate samples, whereas the third showed an increase in the dominance of Flavobacteria (51.6\% of total sequences in $\mathrm{S}_{64}$-A, Figure 4). Additionally, sequences belonging to the phylum Actinobacteria increased in abundance in all samples ( $\leq 32 \%$ of total sequences). There was not much change in the relative abundance of the bacterial phyla Betaproteobacteria, Bacteriodetes, and Chloroflexi (Figure 4).

TABLE 3 | MiSeq sequencing and bacterial diversity estimators for the untreated and the biostimulated soils $\left(\mathrm{S}_{0}\right.$ : original soil; $\mathrm{S}_{64}$ untreated soil after 64 days of incubation; SG: soil treated with sewage sludge; SB: soil treated with soybean meal and WS: soil treated with wheat straw).

\begin{tabular}{lccccc}
\hline Sample & Replicate & $\begin{array}{c}\text { Total No. of } \\
\text { sequences }\end{array}$ & $\begin{array}{c}\text { No. of } \\
\text { OTUs* }\end{array}$ & Chao-1 & ACE \\
\hline So & A & 92635 & 399 & 540.2 & 533.1 \\
& B & 43103 & 263 & 384.3 & 411.7 \\
S64 & C & 73774 & 240 & 385.6 & 397.2 \\
& A & 104773 & 176 & 288.8 & 308.5 \\
& B & 108467 & 266 & 407.1 & 414.0 \\
SG & C & 73415 & 197 & 315.0 & 331.2 \\
& A & 35845 & 206 & 307.2 & 328.0 \\
& B & 33379 & 198 & 323.1 & 320.4 \\
SB & C & 29766 & 193 & 317.7 & 344.1 \\
& A & 295156 & 246 & 374.4 & 391.6 \\
& B & 27585 & 256 & 451.0 & 457.7 \\
WS & C & 186157 & 255 & 413.4 & 427.7 \\
& A & 44936 & 262 & 422.7 & 447.3 \\
& B & 150844 & 246 & 396.1 & 384.1 \\
& C & 95582 & 238 & 354.5 & 352.1 \\
\hline
\end{tabular}

* Operational taxonomic unit at 3\% sequence dissimilarity based on equal subsets of sequences for all samples, Chao-1 is based on rare OTUs in a given sample and ACE is abundance-based coverage.

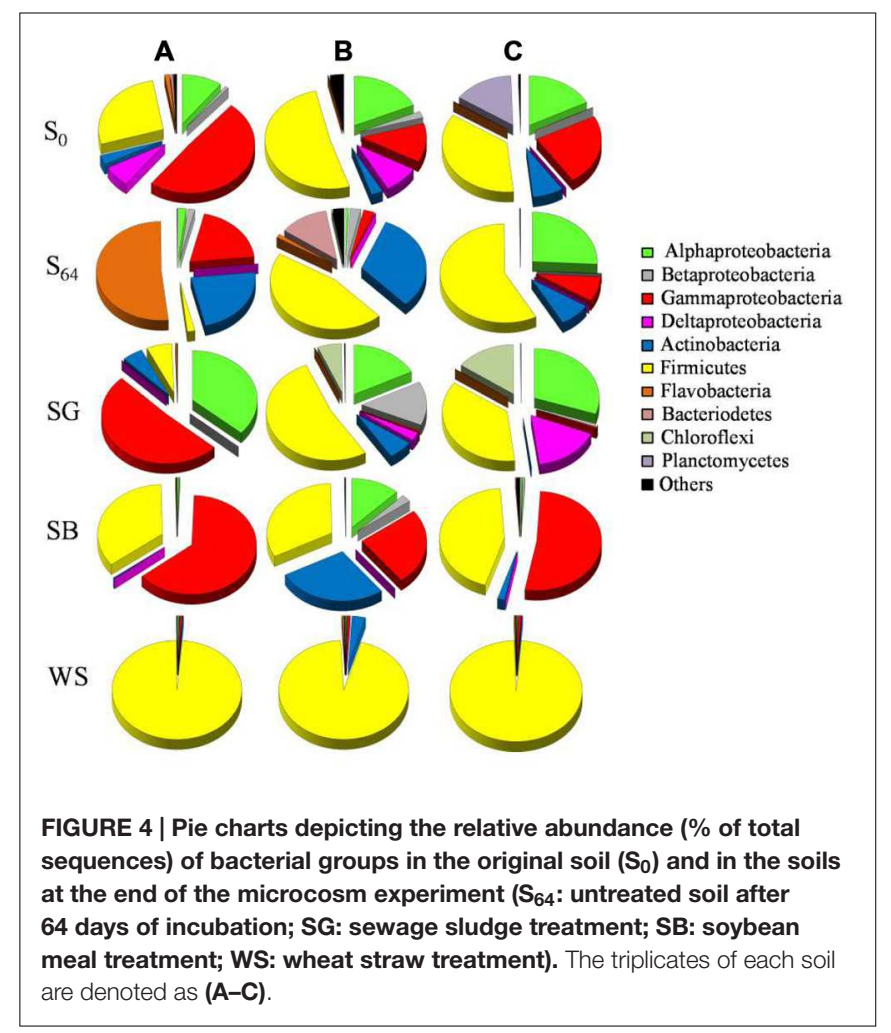

At the genera level, the majority of sequences of Alphaproteobacteria in the untreated soil, at the beginning of the experiment, belonged to the genera Sphingopyxis, Phenylobacterium, and Defluviicoccus (Figure 5). However, after 64 days of incubation, only sequences related to Sphingopyxis persisted in one of the replicas (i.e., $\mathrm{S}_{64}$-C). Gammaproteobacteria was dominated by Pseudomonas, Halomonas, Haemophilus, and Alcanivorx but after incubation, all these genera disappeared and only in one replica, sequences belonging to the genus Enhydrobacter appeared (Figure 5). Sequences related to Bacillus and Streptococcus constituted 


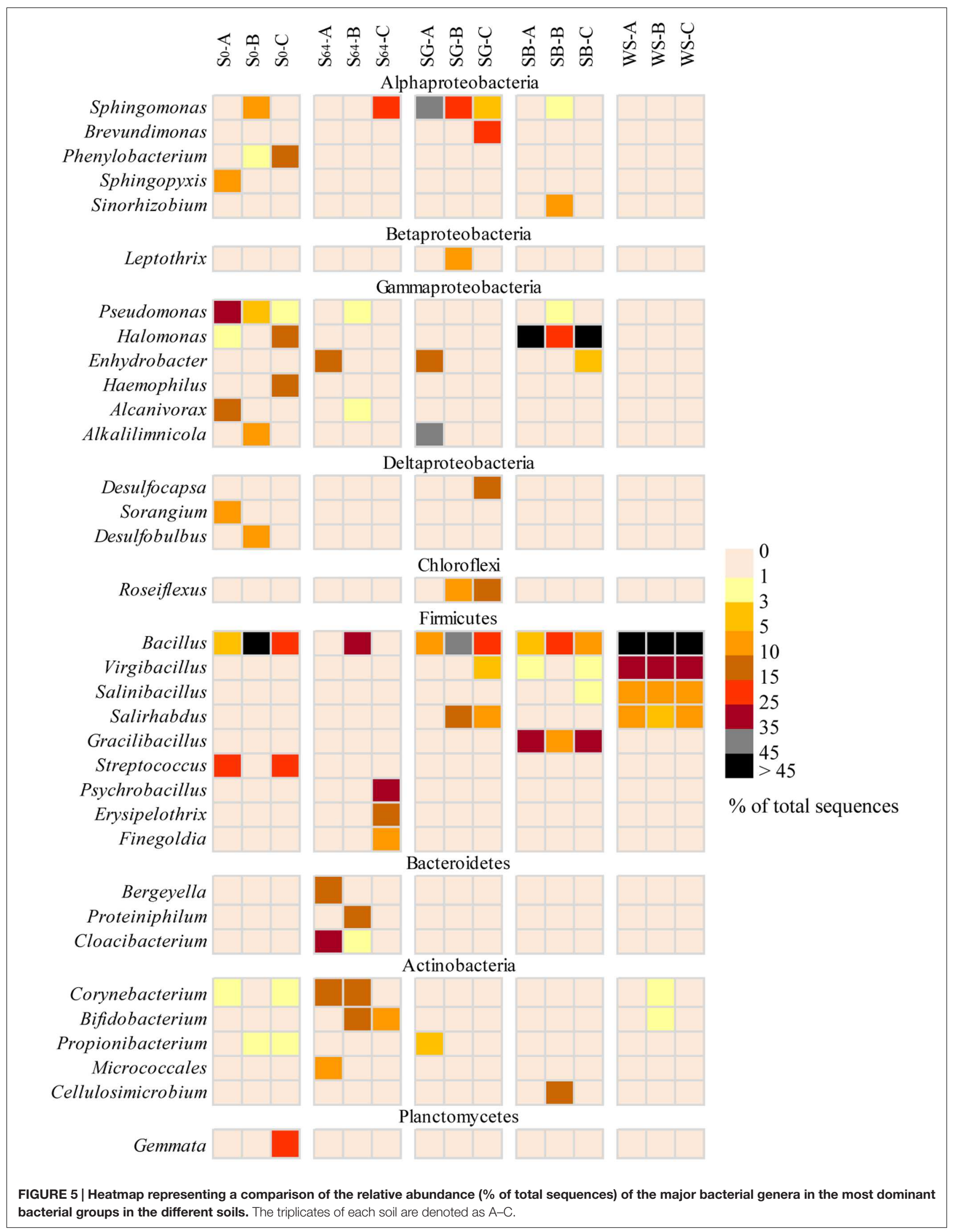


$85-98 \%$ of total sequences of Firmicutes in the original soil. After incubation, Bacillus was still detectable, in addition to two new genera Psychrobacillus and Erysipelothrix. While the phylum Bacteroidetes was dominated by sequences related to Bergeyella, Proteiniphilum and Cloacibacterium, Actinobacteria was dominated by sequences affiliated to Corynebacterium, Bifidobacterium, and Micrococcales (Figure 5).

The addition of SG to the oil-contaminated desert soils induced variable changes in the triplicate samples. While Alphaproteobacteria increased in abundance in all replicates, Gammaproteobacteria increased only in SG-A (51\% of total sequences), Betaproteobacteria increased only in SG-B (14\%) and Deltaproteobacteria increased only in SG-C (17\%). The majority (>98\%) of Aphaproteobacteria belonged to the bacterial genera Sphingomonas and Brevundimonas (Figure 5). Sequences of Gammaproteobacteria were related to the genera Alkalilimnicola and Enhydrobacter whereas sequences belonging to Betaproteobacteria and Deltaproteobacteria were dominated by the genera of Leptothrix and Desulfocapsa, respectively (Figure 5). Actinobacteria was detectable in all replicates, but at a lower abundance (i.e., $0.2-6 \%$ of total sequences) than the untreated soil. In contrast, the relative abundance of Chloroflexi increased at least in two replicates to reach $\leq 15 \%$ of the total sequences and the only detectable genus was Roseiflexus (Figure 5). Most of the Firmicutes sequences were affiliated to Bacillus, Salirhabdus, and Virgibacillus and were mainly dominating the samples SG-B and SG-C (Figure 5).

In the case of the addition of $\mathrm{SB}$, Gammaproteobacteria and Firmicutes constituted between 58 and $99 \%$ of total sequences in all soil samples (Figure 4). While 91-99\% of the gammaproteobacterial sequences were affiliated to the genus Halomonas, 89-90\% of the Firmicutes sequences belonged to Bacillus and Gracilibacillus (Figure 5). In one replica, Actinobacteria and Alphaproteobacteria made up ca. 12 and $27 \%$ of total sequences, respectively whereas in the other two replicas, both bacterial groups made up $\leq 2.5 \%$ (Figure 4). These sequences were mainly affiliated to the genera Sphingomonas, Sinorhizobium, and Cellulosimicrobium (Figure 5). The remaining bacterial groups remained at a relative abundance of $\leq 2 \%$ of total sequences each in all samples.

The addition of WS to the contaminated soils induced the most remarkable changes in the bacterial community composition. The whole community shifted in the favor of the Firmicutes group, which made up 95-98\% of total sequences in all samples (Figure 4). The dominating genera in this group were Bacillus, Virgibacillus, Salinibacillus, and Salirhabdus (Figure 5).

\section{DISCUSSION}

Our data demonstrated a greater effect of SG and WS than SB in the stimulation of respiration activities and oil degradation rates in the oil-contaminated desert soil. The addition of these agents has been shown to enrich soils with nutrients, such as phosphorous and nitrogen, whose limitation is known to slow down biodegradation processes (Cui et al., 2008; Chorom et al., 2010; Agamuthu et al., 2013). Although the addition of SB increased oil degradation rates, as revealed by GC-MS analysis, its effect on respiration activities was insignificant. This could be attributed to the active microbial community in the used $\mathrm{SB}$, as suggested by the high amount of produced $\mathrm{CO}_{2}$ by the $\mathrm{SB}$ alone $\left(50.0 \pm 1.9 \mathrm{mg} \mathrm{CO} \mathrm{g}^{-1}\right.$ soil). These exogenous bacteria could compete for the available organics and nutrients with the indigenous bacteria in the contaminated soil. Furthermore, it is not clear whether the measured $\mathrm{CO}_{2}$, which represents net production, originated from the mineralization of oil components or from other organics in the SB. We speculate that a fraction of the SB and the soil bacterial communities switched between feeding on the SB organics and feeding on hydrocarbons, resulting in the same net production of $\mathrm{CO}_{2}$. Although, the addition of SB resulted in an increase of only $30 \%$ in alkane degradation in our experiments, previous studies showed an increase in the degradation of motor oil and phenol to reach $60-90 \%$ upon the addition of SB and soybean seed hull (Flock, 1998; Diab, 2013). SB was even used in the bioremediation of palm oil mill effluent (Ibegbulam-Njoku and Achi, 2014).

The use of $\mathrm{CO}_{2}$ evolution as a measure of oil mineralization has been successfully used in several reports (Boufadel et al., 1999; Kim et al., 2005; Morais and Tauk-Tornisielo, 2009; Abed et al., 2014; Personna et al., 2014). However, in our experiments, we could not reliably calculate oil mineralization from the produced $\mathrm{CO}_{2}$, since the added biostimulating agents could act as an additional carbon source to oil. In spite of that, there was a good correlation between the total amounts of degraded alkanes, measured using GC-MS, and the amounts of cumulative produced $\mathrm{CO}_{2}$ (Table 2) in the untreated and treated soils in the bottle experiment $(r=0.75, P \leq 0.01)$. Such positive correlation, where the produced $\mathrm{CO}_{2}$ increases with increasing degradation of hydrocarbons, has been previously observed (Namkoong et al., 2002). The ratios of degraded alkanes to the amount of produced $\mathrm{CO}_{2}$ in the SG and WS treated soils, after subtracting the produced $\mathrm{CO}_{2}$ from soil-free SG and WS, were 0.66 and 0.81 , respectively. Previous studies have reported values between 0.8 and 1.4 (Hwang et al., 2006). Our values were lower than those reported previously, mainly because our calculation was based on the amounts of degraded alkanes, which is a fraction of oil, and not on the total TPH. Moreover, it is known that a fraction of the carbon could be assimilated into biomass (Linton and Stephenson, 1978). Using GC-MS, the degradation of alkanes was slightly higher $(P<0.05)$ in the bottle experiment than in the microcosm experiment. However, when the incubation period is taken into account (i.e., 110 vs. 64 days), the degradation rates were still higher in the microcosm experiment (i.e., 0.172 and 0.166 vs. 0.29 and $0.28 \mathrm{mg}$ of alkanes $\mathrm{g}^{-1}$ soil day ${ }^{-1}$, for SG and WS amended soils, respectively). This is due to the clear differences in the incubation conditions between the bottle and the microcosm experiments, including water content, aeration, mixing, and scale. The continuous supply of oxygen in the microcosm experiment due to soil tilting apparently favored oil degradation.

Previous reports have used SG for bioremediation of oilcontaminated soils because of its richness in nutrients and the existence of high diversity and density of microorganisms therein (Chang et al., 2003; Gestel et al., 2003; Ros et al., 
2010; Ambrazaitiene et al., 2013). However, the low respiration activities of SG suggests a low activity of its microbial community. The remarkable increase in the produced $\mathrm{CO}_{2}$ after the addition of SG to the contaminated soil indicates that SG was most likely a good source of nutrients. Previous reports showed that the addition of SG to diesel- and oil-contaminated soils resulted in a total degradation rate of $46-98 \%$ of TPHs (Namkoong et al., 2002; Hur and Park, 2003; Ros et al., 2010; Chorom and Hosseini, 2011). Although, the use of 5\% (w/w) SG in our experiments was effective, the use of as high as 10 and as low as $1 \%$ was also shown to stimulate oil degradation rates (Hur and Park, 2003; Ros et al., 2010; Chorom and Hosseini, 2011). On the contrary, the excessive use of SG retarded the biodegradation of TPH in other cases (Namkoong et al., 2002).

The bioventing agent, WS, stimulated respiration activities and oil mineralization rates in the oil-contaminated desert soils. Since the studied desert soil had a silt loam texture with $50 \%$ silt, it is plausible that the addition of WS resulted in an increase in the soil porosity and oxygen availability to the oil-degrading bacteria. Previous biostimulation studies using WS reported degradation rates between 59 and $85 \%$ during a period of $1-$ 3 months (Vasudevan and Rajaram, 2001; Marin et al., 2006; Rojas-Avelizapa et al., 2007). Other studies have used WS as a source of inorganic nutrients such as $\mathrm{N}$ and $\mathrm{P}$ and organic nutrients such as cellulose and hemicellulose (Zhang et al., 2008; Llado et al., 2015). It was postulated that the decomposition products of cellulose and hemicellulose promote the growth of bacteria including the oil-degrading types. WS was also used to enhance bioremediation in salty contaminated soils, where high salt levels may inhibit microbial growth, by cutting capillaries and decreasing salt accumulation at the soil surface (Zhang et al., 2008). This effect was shown to result in a remarkable increase in bacterial biomass and in an increase in TPH degradation from 29 to $48 \%$ (Zhang et al., 2008).

\section{Bacterial Diversity and its Changes in the Untreated Desert Soil}

MiSeq data showed shifts in the bacterial community structure of untreated as well as in biostimulated soils. The original desert soil was dominated by sequences belonging to the bacterial groups Alphaproteobacteria, Gammaproteobacteria and Firmicutes, and these groups have been previously encountered in oil-contaminated soils, including desert soils (Militon et al., 2010; dos Santos et al., 2011; Sutton et al., 2013). Several members of these bacterial groups are known for their ability to degrade aliphatic and aromatic hydrocarbons (Alonso-Gutierrez et al., 2008; Lafortune et al., 2009; Vila et al., 2010; Kostka et al., 2011). Among the detected genera in our desert soil that potentially contain hydrocarbon-degrading species were Sphingomonas, Phenylobacterium, Sphingopyxis, Pseudomonas, Halomonas, and Alcanivorax. The detection of these genera in the original soil suggests that oil-degradation could be naturally occurring in the soil even without any treatment. This process, which relies on the activity of indigenous oil-degrading microorganisms, is known as natural attenuation and has become an accepted low-risk and cost-effective bioremediation approach (Margesin and Schinner,
2001; Bento et al., 2005; Ruberto et al., 2009). The produced $\mathrm{CO}_{2}$ levels and the measured natural degradation by GC-MS analysis in the untreated soil support the occurrence of natural biodegradation in the untreated soil.

Species belonging to the Alphaproteobacterial genera Sphingomonas, Phenylobacterium, and Sphingopyxis in the original soil have been previously detected in oil-contaminated environments and have been known for many years to contain degraders of PAHs (Tao et al., 2007; Lan et al., 2011; Yang et al., 2014; Zhang et al., 2014; Ronca et al., 2015). For instance, Sphingomonas sp. was shown to utilize phenanthrene as its exclusive source of carbon and energy (Tao et al., 2007) and to degrade $83 \%$ of applied diesel and $3-79 \%$ of mixed PAHs (Cui et al., 2008). Phenylobacterium and Sphingopyxis spp. were also shown to degrade several aromatic hydrocarbons as a carbon source (Eberspaecher and Lingens, 2006; Kertesz and Kawasaki, 2010; Lan et al., 2011; Kim et al., 2014; Yang et al., 2014). Similarly, strains of the genera Pseudomonas, Alcanivorax and Halomonas, which prevailed the class Gammaproteobacteria, are renowned for their global distribution in contaminated sites and for their ability to degrade hydrocarbons (Hara et al., 2003; Schneiker et al., 2006; Mnif et al., 2009; Linda and Bouziane, 2012; Oyetibo et al., 2013). The two dominant genera of the phylum Firmicutes; Bacillus and Streptococcus, have also been previously detected in contaminated soils with an active role in the degradation process (Makut and Ishaya, 2010; Mansur et al., 2014).

The incubation of the soil for 64 days in microcosms, even without any treatment, induced clear shifts in the microbial community composition. It is known that confined incubation of bacterial samples results in changes in the composition of bacterial community structure, an effect known as "bottle effect" (Hammes et al., 2010). While the abundance of Flavobacteria increased in $\mathrm{S}_{64}-\mathrm{A}$, the abundance of Actinobacteria increased in $\mathrm{S}_{64}-\mathrm{A}$ and $\mathrm{S}_{64}-\mathrm{B}$ and the abundance of Firmicutes increased in $\mathrm{S}_{64}$-C. Genera affiliated to Firmicutes and Actinobacteria are known for their vast distribution in oil-contaminated soils and they contain strains that were able to degrade hydrocarbons. Actinobacteria play a central role in the decomposition of organic matter and recycling of nutrients (Prince et al., 2010). Among the detected Actinobacterial genera known to degrade hydrocarbons are Corynebacterium and Micrococcus (Santhini et al., 2009; Oyetibo et al., 2013; Hassanshahian et al., 2014).

\section{Post-biostimulation Bacterial Community Shifts}

The relative abundance of the bacterial groups exhibited high variability among the triplicate samples of each treatment, making it difficult to attribute specific shifts in the bacterial community to the applied treatment. Nevertheless, NMDS ordination based on the different treatments placed the microbial communities in separate clusters and this dissimilarity was supported by an ANOSIM $R$ value of 0.66 . This suggests that, in spite of the heterogeneity in the triplicate soil samples of each treatment, the species composition still varied between the different treatments. Moreover, the persistence of the same 
bacterial groups after treatment indicates that these groups still favored the new conditions. In the SG-treated soils, the relative abundance of Alphaproteobacteria remained the same or increased in all replicates, whereas the abundance of Firmicutes, Gammaproteobacteria and Chloroflexi increased in some replicates but not in others. The alphaproteobacterial genera Sphingomonas and Brevundimonas, which constituted 35 and $20.4 \%$ of the total sequences, respectively are known to include species that degrade petroleum compounds (Ijah and Ukpe, 1992; Baraniecki et al., 2002; Vazquez et al., 2013). The persistence of the Firmicutes group after biostimulation with SG indicates that this group constitutes a stable and vital component of the bacterial community structure of the desert soil. Sequences in this group are prevailed by Bacillus, Salirhabdus and Virgibacillus, which are known to have oil-degrading species (Kothari et al., 2013; Borah and Yadav, 2014; Roy et al., 2014; Albokari et al., 2015). The detection of sequences belonging to the class Chloroflexi only in the treatment with SG and not in others, strongly suggests that these bacteria have been growing in the sludge and brought into the soil. The green nonsulfur Chloroflexi bacteria were previously found abundant in wastewater treatment plants (Bjornsson et al., 2002; Kragelund et al., 2007; An et al., 2013).

In the soil amended with SB, Firmicutes persisted while Gammaproteobacteria increased in abundance to reach 25$63 \%$ of total sequences, of which $97 \%$ were affiliated with the genus Halomonas. The detection of high abundance of Halomonas in this treatment suggests that these bacteria were introduced by the SB or favored the growth on the organics therein. This assumption is supported by the produced $\mathrm{CO}_{2}$ of soybean alone, which indicated the presence of an active bacterial community. Although the genus Halomonas is known to include oil-degrading species (Mnif et al., 2009; D’Ippolito et al., 2011), most of the detected sequences were affiliated to the species Halomonas xinjiangensis, which was isolated from a pristine soil and is unable to degrade hydrocarbons (Guan et al., 2010). The amendment of the soil with WS induced the most remarkable shift in the bacterial community, indicating that WS created different conditions in this treatment that favored the growth of Firmicutes species. Although the phylum Firmicutes includes both aerobic and anaerobic microorganisms, all detected species in this treatment belonged to aerobic Bacilli-related species.

\section{REFERENCES}

Abed, R. M. M., Al-Sabahi, J., Al-Maqrashi, F., Al-Habsi, A., and Al-Hinai, M. (2014). Characterization of hydrocarbon-degrading bacteria isolated from oil-contaminated sediments in the Sultanate of Oman and evaluation of bioaugmentation and biostimulation approaches in microcosm experiments. Int. Biodeterior. Biodegradation 89, 58-66. doi: 10.1016/j.ibiod.2014.01.006

Agamuthu, P., Tan, Y. S., and Fauziah, S. H. (2013). Bioremediation of hydrocarbon contaminated soil using selected organic wastes. Procedia Environ. Sci. 18, 694-702. doi: 10.1016/j.proenv.2013.04.094

Albokari, M., Mashhour, I., Alshehri, M., Boothman, C., and Al-Enezi, M. (2015). Characterization of microbial communities in heavy crude oil from Saudi Arabia. Ann. Microbiol. 65, 95-104. doi: 10.1007/s13213-014-0840-0

Alonso-Gutierrez, J., Costa, M. M., Figueras, A., Albaiges, J., Vinas, M., Solanas, A. M., et al. (2008). Alcanivorax strain detected among the cultured bacterial
This suggests that WS probably acted as a bioventing agent and increased oxygen penetration in the soil. Bacilli strains are known to include many oil-degrading species and were even detected in crude oils (Ijah and Ukpe, 1992; Khanna et al., 2012; Borah and Yadav, 2014). An interesting feature of Bacilli strains is their ability to produce biosurfactants, which increase the bioavailability of oil through emulsification and consequently facilitate the degradation process (Cubitto et al., 2004; Yamane et al., 2008; Perfumo et al., 2010; Najafi et al., 2011; Chandankere et al., 2013).

We conclude that SG, WS, and SB are suitable bioremediation agents that can be successfully used to enhance the activity of oildegrading bacteria and facilitate the degradation of petroleum contaminants in desert soils. SG and WS had a stronger stimulatory effect on the soil's respiration activities and oil degradation than SB. Microbial community analysis revealed the dominance of sequences affiliated to Alphaproteobacteria, Gammaproteobacteria, and Firmicutes in the original soil, although there was a clear heterogeneity among the triplicate samples. The relative abundance of these groups showed variations after the addition of the biostimulating agents, with the most prominent shift in the case of WS-treated soils, where almost the whole community was composed of Bacilli.

\section{AUTHOR CONTRIBUTIONS}

SA-K and RA designed the experiments, SA-K performed the experiments and the chemical analysis using GC-MS, RA did the molecular work and the bioinformatics analysis. SA-K and RA wrote the manuscript.

\section{ACKNOWLEDGMENTS}

We would like to thank Mr. Abdulla Al-Harthy for his help in sample collection and Mr. Jamal Al-Sabahi for his assistance in the chemical analysis. We are also grateful for Gulf Mushroom Products Company (S.A.O.G) in Barka, Oman for their help in the collection of wheat straw and soybean meal. This research was financially supported by The Research Council (TRC) of Oman (grant RC/SCI/BIOL/11/01).

community from sediments affected by the 'Prestige' oil spill. Mar. Ecol. Prog. Ser. 362, 25-36. doi: 10.3354/meps07431

Ambrazaitiene, D., Zukauskaite, A., Jakubauskaite, V., Reikaite, R., Zubrickaite, M., and Karcauskiene, D. (2013). Biodegradation activity in the soil contaminated with oil products. Zemdirbyste 100, 235-242. doi: 10.13080/z-a.2013.100.030

An, D., Brown, D., Chatterjee, I., Dong, X., Ramos-Padron, E., Wilson, S., et al. (2013). Microbial community and potential functional gene diversity involved in anaerobic hydrocarbon degradation and methanogenesis in an oil sands tailings pond. Genome 56, 612-618. doi: 10.1139/gen-2013-0083

Baraniecki, C. A., Aislabie, J., and Foght, J. M. (2002). Characterization of Sphingomonas sp. Ant 17, an aromatic hydrocarbon-degrading bacterium isolated from Antarctic soil. Microb. Ecol. 43, 44-54. doi: 10.1007/s00248-0011019-3

Bento, F. M., Camargo, F. A. O., Okeke, B. C., and Frankenberger, W. T. (2005). Comparative bioremediation of soils contaminated with diesel oil by natural 
attenuation, biostimulation and bioaugmentation. Bioresour. Technol. 96, 10491055. doi: 10.1016/j.biortech.2004.09.008

Bjornsson, L., Hugenholtz, P., Tyson, G. W., and Blackall, L. L. (2002). Filamentous Chloroflexi (green non-sulfur bacteria) are abundant in wastewater treatment processes with biological nutrient removal. Microbiology 148, 2309-2318. doi: 10.1099/00221287-148-8-2309

Borah, D., and Yadav, R. N. S. (2014). Biodegradation of diesel, crude oil, kerosene and used engine oil by a newly isolated Bacillus cereus strain DRDU1 from an automobile engine in liquid culture. Arab. J. Sci. Eng. 39, 5337-5345. doi: 10.1007/s13369-014-1118-3

Boufadel, M. C., Reeser, P., Suidan, M. T., Wrenn, B. A., Cheng, J., Du, X., et al. (1999). Optimal nitrate concentration for the biodegradation of $n$-heptadecane in a variably-saturated sand column. Exp. Technol. 20, 191-199.

Brady, N. C. (1984). The Nature and Properties of Soil. New York, NY: Macmillan Book Co.

Chandankere, R., Yao, J., Choi, M. M. F., Masakorala, K., and Chan, Y. (2013). An efficient biosurfactant-producing and crude-oil emulsifying bacterium Bacillus methylotrophicus USTBa isolated from petroleum reservoir. Biochem. Eng. J. 74, 46-53. doi: 10.1016/j.bej.2013.02.018

Chang, B. V., Chang, S. W., and Yuan, S. Y. (2003). Anaerobic degradation of polycyclic aromatic hydrocarbons in sludge. Adv. Environ. Res. 7, 623-628. doi: 10.1016/S1093-0191(02)00047-3

Chorom, M., and Hosseini, S. S. (2011). Bioremediation of crude oil-polluted soil by sewage sludge. Pedologist 54, 294-301.

Chorom, M., Sharifi, H. S., and Motamedi, H. (2010). Bioremediation of crude oilpolluted soil by application of fertilizers. Iranian J. Environ. Health Sci. Eng. 7, 319-326.

Clarke, K. R. (1993). Non-parametric multivariate analysis of changes in community structure. Aust. J. Ecol. 18, 117-143. doi: 10.1007/s00248-0099590-0

Cubitto, M. A., Moran, A. C., Commendatore, M., Chiarello, M. N., Baldini, M. D., and Sineriz, F. (2004). Effects of Bacillus subtilis O9 biosurfactant on the bioremediation of crude oil polluted soils. Biodegradation 15, 281-287. doi: 10.1023/B:BIOD.0000042186.58956.8f

Cui, Z., Lai, Q., Dong, C., and Shao, Z. (2008). Biodiversity of polycyclic aromatic hydrocarbon degrading bacteria from deep sea sediments of the Middle Atlantic Ridge. Environ. Microbiol. 10, 2138-2149. doi: 10.1111/j.14622920.2008.01637.x

De Santis, T. Z., Hugenholtz, P., Larsen, N., Rojas, M., Brodie, E. L., Keller, K., et al. (2006). Greengenes, a chimera-checked 16S rRNA gene database and workbench compatible with ARB. Appl. Environ. Microbiol. 72, 5069-5072. doi: 10.1128/AEM.03006-05

Diab, A., and Sandouka, M. (2012). Effect of phytogenic biosurfactant on the microbial community and on the bioremediation of highly oil- polluted desert soil. J. Am. Sci. 8, 544-550.

Diab, E. A. (2013). Application of plant residues and biosurfactants: a cost effective strategies for the bioremediation of spent motor oil contaminated soil. Int. J. Sci. Res. (Raipur) 4, 2836.

D'Ippolito, S., De Castro, R. E., and Herrera Seitz, K. (2011). Chemotactic responses to gas oil of Halomonas spp. strains isolated from saline environments in Argentina. Rev. Argent. Microbiol. 43, 107-110. doi: 10.1590/S032575412011000200007

dos Santos, H. F., Cury, J. C., do Carmo, F. L., dos Santos, A. L., Tiedje, J., van Elsas, J. D., et al. (2011). Mangrove bacterial diversity and the impact of oil contamination revealed by pyrosequencing: bacterial proxies for oil pollution. PLOS ONE 6:e16943. doi: 10.1371/journal.pone. 0016943

Eberspaecher, J., and Lingens, F. (2006). "The genus phenylobacterium," in Prokaryotes: A Handbook on the Biology of Bacteria, eds M. Dworkin, S. Falkow, E. Rosenberg, K. H. Schleifer, and E. Stackebrandt (New York, NY: Springer), $250-256$.

Flock, C. (1998). Bioremediation of Phenols and Chlorophenols with Soybean Peroxidase (SBP) and Crude Soybean seed Hulls: Modeling and Experimental Studies. Ph.D. dissertation, The University of Western Ontario, London, ON.

Gallego, J. L. R., Loredo, J., Llamas, J. F., Vazquez, F., and Sanchez, J. (2001). Bioremediation of diesel-contaminated soils: evaluation of potential in situ techniques by study of bacterial degradation. Biodegradation 12, 325-335. doi: 10.1023/A:1014397732435
Gestel, V. K., Mergaert, J., Swings, J., Coosemans, J., and Ryckeboer, J. (2003). Bioremediation of diesel oil-contaminated soil by composting with biowaste. Environ. Pollut. 125, 361-368.

Guan, T.-W., Xiao, J., Zhao, K., Luo, X.-X., Zhang, X.-P., and Zhang, L.-L. (2010). Halomonas xinjiangensis sp. nov., a halotolerant bacterium isolated from a salt lake. Int. J. Syst. Evol. Microbiol. 60, 349-352. doi: 10.1099/ijs.0.01 1593-0

Hamdi, H., Manusadzianas, L., Aoyama, I., and Jedidi, N. (2006). Effects of anthracene, pyrene and benzo a pyrene spiking and sewage sludge compost amendment on soil ecotoxicity during a bioremediation process. Chemosphere 65, 1153-1162. doi: 10.1016/j.chemosphere.2006.03.065

Hammes, F., Vital, M., and Egli, T. (2010). Critical evaluation of the volumetric "Bottle Effect" on microbial batch growth. Appl. Environ. Microbiol. 76, 12781281. doi: 10.1128/AEM.01914-09

Hara, A., Syutsubo, K., and Harayama, S. (2003). Alcanivorax which prevails in oil-contaminated seawater exhibits broad substrate specificity for alkane degradation. Environ. Microbiol. 5, 746-753. doi: 10.1046/j.1468-2920.2003.00468.x

Hassanshahian, M., Zeynalipour, M. S., and Musa, F. H. (2014). Isolation and characterization of crude oil degrading bacteria from the Persian Gulf (Khorramshahr provenance). Mar. Pollut. Bull. 82, 39-44. doi: 10.1016/j.marpolbul.2014.03.027

Hazen, T. C. (2010). "Biostimulation," in Handbook of Hydrocarbon and Lipid Microbiology, ed. K. Timmis (Heidberg: Springer-Verlag), 4518-4530.

Hu, M., Wang, X., Wen, X., and Xia, Y. (2012). Microbial community structures in different wastewater treatment plants as revealed by 454 -pyrosequencing analysis. Bioresour. Technol. 117, 72-79. doi: 10.1016/j.biortech.2012.04.061

Huang, D. L., Zeng, G. M., Jiang, X. Y., Feng, C. L., Yu, H. Y., Huang, G. H., et al. (2006). Bioremediation of $\mathrm{Pb}$-contaminated soil by incubating with Phanerochaete chrysosporium and straw. J. Hazard. Mater. 134, 268-276. doi: 10.1016/j.jhazmat.2005.11.021

Hur, J. M., and Park, J. A. (2003). Effect of sewage sludge mix ratio on the biodegradation of diesel-oil in a contaminated soil composting. Korean J. Chem. Eng. 20, 307-314. doi: 10.1007/BF02697246

Hwang, E.-Y., Park, J.-S., Kim, J.-D., and Namkoong, W. (2006). Effects of aeration mode on the composting of diesel-contaminated soil. J. Ind. Eng. Chem. 12, 694-701.

Ibegbulam-Njoku, P. N., and Achi, O. K. (2014). Use of fungi in bioremediation of palm oil mill effluent (POME). Int. J. Adv. Res. Technol. 3, 1-8.

Ijah, U. J. J., and Ukpe, L. I. (1992). Biodegradation of crude oil by Bacillus strains 28A and 61B isolated from oil spilled soil. Waste Manag. 12, 55-60. doi: 10.1016/0956-053X(92)90009-8

Kertesz, M. A., and Kawasaki, A. (2010). "Hydrocarbon-degrading Sphingomonads: Sphingomonas, Sphingobium, Novosphingobium, and Sphingopyxis," in Handbook of Hydrocarbon and Lipid Microbiology, ed. K. Timmis (Heidelberg: Springer Verlag), 1694-1705.

Khanna, P., Goyal, D., and Khanna, S. (2012). Characterization of pyrene utilizing Bacillus spp. from oil contaminated soil. Braz. J. Microbiol. 43, 606-617. doi: 10.1590/S1517-83822012000200024

Kim, J., Kim, S. J., Kim, S. H., Kim, S., Moon, Y.-J., Park, S.-J., et al. (2014). Draft genome sequence of Sphingopyxis sp. strain MWB1, a crude- oil-degrading marine bacterium. Genome Announc. 2, 1-2. doi: 10.1128/genomeA.01256-14

Kim, S.-J., Choi, D. H., Sim, D. S., and Oh, Y.-S. (2005). Evaluation of bioremediation effectiveness on crude oil-conaminated sand. Chemosphere 59, 845-852. doi: 10.1016/j.chemosphere.2004.10.058

Klindworth, A., Pruesse, E., Schweer, T., Peplies, J., Quast, C., Horn, M., et al. (2013). Evaluation of general 16S ribosomal RNA gene PCR primers for classical and next generation sequencing-based diversity studies. Nucleic Acids Res. 41, el. doi: 10.1093/nar/gks808

Klute, A. (1986). Methods of Soil Analysis. Medison, WI: American Society of Agronomy.

Kostka, J. E., Prakash, O., Overholt, W. A., Green, S. J., Freyer, G., Canion, A., et al. (2011). Hydrocarbon-degrading bacteria and the bacterial community response in Gulf of Mexico beach sands impacted by the deepwater horizon oil spill. Appl. Environ. Microbiol. 77, 7962-7974. doi: 10.1128/AEM.05402-11

Kothari, V., Panchal, M., and Srivastava, N. (2013). Presence of catechol metabolizing enzymes in Virgibacillus salarius. J. Environ. Conserv. Res. 1, 29-36. doi: 10.12966/jecr.08.03.2013 
Kragelund, C., Levantesi, C., Borger, A., Thelen, K., Eikelboom, D., Tandoi, V., et al. (2007). Identity, abundance and ecophysiology of filamentous Chloroflexi species present in activated sludge treatment plants. FEMS Microbiol. Ecol. 59, 671-682. doi: 10.1111/j.1574-6941.2006.00251.x

Lafortune, I., Juteau, P., Deziel, E., Lepine, F., Beaudet, R., and Villemur, R. (2009). Bacterial diversity of a consortium degrading high-molecular-weight polycyclic aromatic hydrocarbons in a two-liquid phase biosystem. Microb. Ecol. 57, 455-468. doi: 10.1007/s00248-008-9417-4

Lamendekka, R., Strutt, S., Borglin, S., Chakraborty, R., Tas, N., Mason, O. U., et al. (2014). Assessment of the deep horizon oil spill impact on Gulf coast microbial communities. Front. Microbiol. 5:130. doi: 10.3389/fmicb.2014. 00130

Lan, G., Li, Z., Zhang, H., Zou, C., Qiao, D., and Cao, Y. (2011). Relationship of microbial diversity from recycled injection water and hightemperature petroleum reservoirs analyzed by polymerase chain reaction denaturing gradient gel electrophoresis (PCR DGGE). Afr. J. Biotechnol. 10, $11004-11010$

Lang, E., Kleeberg, I., and Zadrazil, F. (2000). Extractable organic carbon and counts of bacteria near the lignocellulose-soil interface during the interaction of soil microbiota and white rot fungi. Bioresour. Technol. 75, 57-65. doi: 10.1016/S0960-8524(00)00031-6

Linda, A., and Bouziane, A. (2012). Petroleum-oil biodegradation by Corynebacterium aquaticum and Pseudomonas aeruginosa strains isolated from the industrial rejection of the refinery of ARZEW-Algeria. World Appl. Sci. 18, 1119-1123.

Linton, J. D., and Stephenson, R. J. (1978). A preliminary study on growth yields in relation to the carbon and energy content of various organic growth substrates. FEMS Microbiol. Lett. 3, 95-98. doi: 10.1111/j.1574-6968.1978.tb01891.x

Llado, S., Covino, S., Solanas, A. M., Petruccioli, M., D’Annibale, A., and Vinas, M. (2015). Pyrosequencing reveals the effect of mobilizing agents and lignocellulosic substrate amendment on microbial community composition in a real industrial PAH-polluted soil. J. Hazard. Mater. 283, 35-43. doi: 10.1016/j.jhazmat.2014.08.065

Makut, M. D., and Ishaya, P. (2010). Bacterial species associated with soils contaminated with used petroleum products in Keffi town, Nigeria. Afr. J. Microbiol. Res. 4, 1698-1702.

Mansur, A. A., Adetutu, E. M., Kadali, K. K., Morrison, P. D., Nurulita, Y., and Ball, A. S. (2014). Assessing the hydrocarbon degrading potential of indigenous bacteria isolated from crude oil tank bottom sludge and hydrocarboncontaminated soil of Azzawiya oil refinery, Libya. Environ. Sci. Pollut. Res. Int. 21, 10725-10735. doi: 10.1007/s11356-014-3018-1

Margesin, R., and Schinner, F. (2001). Biodegradation and bioremediation of hydrocarbons in extreme environments. Appl. Microbiol. Biotechnol. 56, 650663. doi: $10.1007 / \mathrm{s} 002530100701$

Marin, J. A., Moreno, J. L., Hernandez, T., and Garcia, C. (2006). Bioremediation by composting of heavy oil refinery sludge in semiarid conditions. Biodegradation 17, 251-261. doi: 10.1007/s10532-005-5020-2

Militon, C., Boucher, D., Vachelard, C., Perchet, G., Barra, V., Troquet, J., et al. (2010). Bacterial community changes during bioremediation of aliphatic hydrocarbon contaminated soil. FEMS Microbiol. Ecol. 74, 669-681. doi: 10.1111/j.1574-6941.2010.00982.x

Mnif, S., Chamkha, M., and Sayadi, S. (2009). Isolation and characterization of Halomonas sp strain C2SS100, a hydrocarbon-degrading bacterium under hypersaline conditions. J. Appl. Microbiol. 107, 785-794. doi: 10.1111/j.13652672.2009.04251.x

Morais, E. B., and Tauk-Tornisielo, S. M. (2009). Biodegradation of oil refinery residues using mixed cultures of microorganisms isolated from a landfarming. Braz. Arch. Biol. Technol. 52, 1571-1578. doi: 10.1590/S151689132009000600029

Najafi, A. R., Rahimpour, M. R., Jahanmiri, A. H., Roostaazad, R., Arabian, D., Soleimani, M., et al. (2011). Interactive optimization of biosurfactant production by Paenibacillus alvei ARN63 isolated from an Iranian oil well. Colloids Surf. B Biointerfaces 82, 33-39. doi: 10.1016/j.colsurfb.2010.08.010

Namkoong, W., Hwang, E. Y., Park, J. S., and Choi, J. Y. (2002). Bioremediation of diesel contaminated soil with composting. Environ. Pollut. 119, 23-31. doi: 10.1016/S0269-7491(01)00328-1

Odokuma, L. O., and Dickson, A. A. (2003). Bioremediation of a crude oil polluted tropical mangrove environment. J. Appl. Sci. Environ. Manag. 7, 23-29.
Oyetibo, G. O., Ilori, M. O., Obayori, O. S., and Amund, O. O. (2013). Biodegradation of petroleum hydrocarbons in the presence of nickel and cobalt. J. Basic Microbiol. 53, 917-927. doi: 10.1002/jobm.201200151

Park, J. H., Lamb, D., Paneerselvam, P., Choppala, G., Bolan, N., and Chung, J.-W. (2011). Role of organic amendments on enhanced bioremediation of heavy metal(loid) contaminated soils. J. Hazard. Mater. 185, 549-574. doi: 10.1016/j.jhazmat.2010.09.082

Perfumo, A., Smyth, T., Marchant, R., and Banat, I. (2010). "Production and roles of biosurfactants and bioemulsifiers in accessing hydrophobic substrates," in Handbook of Hydrocarbon and Lipid Microbiology, ed. K. Timmis (Heidleberg: Springer Verlag), 1501-1512.

Personna, Y. R., King, T., Boufadel, M. C., Zhang, S., and Kustka, A. (2014). Assessing weathered Edicott oil biodegradation in brackish water. Mar. Pollut. Bull. 86, 102-110. doi: 10.1016/j.marpolbul.2014.07.037

Prince, R., Gramain, A., and McGenity, T. (2010). "Prokaryotic hydrocarbon degraders," in Handbook of Hydrocarbon and Lipid Microbiology, ed. K. Timmis (Berlin: Springer-Verlag), 1672-1692.

Quinn, G. P., and Keough, M. J. (2002). Experimental Design and Data Analysis for Biologists. Cambridge: Cambridge University Press.

Radwan, S. (2008). "Microbiology of oil-polluted contaminated desert soils and coastal areas in the Arabian Gulf Region," in Microbiology of Extreme Soils. Soil Biology, eds P. Dion and C. S. Nautiyal (Berlin: Springer), 275-298.

Radwan, S. (2009). "Phytoremediation for oily desert soils," in Advances in Applied Bioremediation, eds A. Singh, R. C. Kuhad, and O. P. Ward (Berlin: Springer), 279-298.

Ramette, A., and Tiedje, J. (2007). Multiscale responses of microbial life to spatial distance and environmental heterogeneity in a patchy ecosystem. Proc. Natl. Acad. Sci. U.S.A. 104, 2761-2766. doi: 10.1073/pnas.0610671104

Rhykerd, R., Crews, B., McInnes, K., and Weaver, R. W. (1999). Impact of bulking agents, forced aeration, and tillage on remediation of oil-contaminated soil. Bioresour. Technol. 67, 279-285. doi: 10.1016/S0960-8524(98)00114-X

Rojas-Avelizapa, N. G., Roldan-Carrillo, T., Zegarra-Martinez, H., MunozColunga, A. M., and Fernandez-Linares, L. C. (2007). A field trial for an ex-situ bioremediation of a drilling mud-polluted site. Chemosphere 66, 1595-1600. doi: 10.1016/j.chemosphere.2006.08.011

Ronca, S., Frossard, A., Guerrero, L. D., Makhalanyane, T. P., Aislabie, J. M. and Cowana, D. A. (2015). Draft genome sequence of Sphingomonas sp. strain Ant20, isolated from oil contaminated soil on Ross Island, Antarctica. Genome Announc. 3, e001309-14. doi: 10.1128/genomeA.01309-14

Ros, M., Rodriguez, I., Garcia, C., and Hernandez, T. (2010). Microbial communities involved in the bioremediation of an aged recalcitrant hydrocarbon polluted soil by using organic amendments. Bioresour. Technol. 101, 6916-6923. doi: 10.1016/j.biortech.2010.03.126

Roy, A. S., Baruah, R., Borah, M., Singh, A. K., Boruah, H. P. D., Saikia, N., et al. (2014). Bioremediation potential of native hydrocarbon degrading bacterial strains in crude oil contaminated soil under microcosm study. Int. Biodeterior. Biodegrad. 94, 79-89. doi: 10.1016/j.ibiod.2014.03.024

Ruberto, L., Dias, R., Lo Balbo, A., Vazquez, S. C., Hernandez, E. A., and Mac Cormack, W. P. (2009). Influence of nutrients addition and bioaugmentation on the hydrocarbon biodegradation of a chronically contaminated Antarctic soil. J. Appl. Microbiol. 106, 1101-1110. doi: 10.1111/j.1365-2672.2008. 04073.x

Santhini, K., Myla, J., Sajani, S., and Usharani, G. (2009). Screening of Micrococcus sp from oil contaminated soil with reference to bioremediation. Bot. Res. Int. 2 , 248-252.

Schloss, P. D., Westcott, S. L., Ryabin, T., Hall, J. R., Hartmann, M., Hollister, E. B., et al. (2009). Introducing mothur: open-source, platform-independent, community-s Software for describing and comparing microbial communities. Appl. Environ. Microbiol. 75, 7537-7541. doi: 10.1128/AEM.01541-09

Schneiker, S., dos Santos, V. A. P. M., Bartels, D., Bekel, T., Brecht, M., Buhrmester, J., et al. (2006). Genome sequence of the ubiquitous hydrocarbondegrading marine bacterium Alcanivorax borkumensis. Nat. Biotechnol. 24, 997-1004. doi: 10.1038/nbt1232

Shokralla, S., Spall, J., Gibson, J. F., and Hajibabaei, M. (2012). Next-generation sequencing technologies for environmental DNA research. Mol. Ecol. 21, 17941805. doi: 10.1111/j.1365-294X.2012.05538.x

Singleton, D. R., Jones, M. D., Richardson, S. D., and Aitken, M. D. (2013). Pyrosequencing analyses of bacterial communities during simulated in situ 
bioremediation of polycyclic aromatic hydrocarbon-contaminated soil. Appl. Microbiol. Biotechnol. 97, 8381-8391. doi: 10.1007/s00253-012-4531-0

Sun, W., Dong, Y., Gao, P., Fu, M., Ta, K., and Li, J. (2015). Microbial communities inhabiting oil contaminated soils from two major oilfields in Northern China: implications for active petroleum degrading capacity. J. Microbiol. 53, 371-378. doi: 10.1007/s12275-015-5023-6

Sutton, N. B., Maphosa, F., Morillo, J. A., Abu Al-Soud, W., Langenhoff, A. A. M., Grotenhuis, T., et al. (2013). Impact of long-term diesel contamination on soil microbial community structure. Appl. Environ. Microbiol. 79, 619-630. doi: 10.1128/AEM.02747-12

Tao, X.-Q., Lu, G.-N., Dang, Z., Yang, C., and Yi, X.-Y. (2007). A phenanthrenedegrading strain Sphingomonas sp GY2B isolated from contaminated soils. Process Biochem. 42, 401-408. doi: 10.3390/ijerph6092470

Vasudevan, N., and Rajaram, P. (2001). Bioremediation of oil sludge-contaminated soil. Environ. Int. 26, 409-411. doi: 10.1016/S0160-4120(01)00020-4

Vazquez, S., Nogales, B., Ruberto, L., Mestre, C., Christie-Oleza, J., Ferrero, M., et al. (2013). Characterization of bacterial consortia from diesel-contaminated Antarctic soils: towards the design of tailored formulas for bioaugmentation. Int. Biodeterior. Biodegradation 77, 22-30.

Vila, J., Maria, N. J., Mertens, J., Springael, D., and Grifoll, M. (2010). Microbial community structure of a heavy fuel oil-degrading marine consortium: linking microbial dynamics with polycyclic aromatic hydrocarbon utilization. FEMS Microbiol. Ecol. 73, 349-362. doi: 10.1111/j.1574-6941.2010.00902.x

Volossiouk, T., Robb, E. J., and Nazar, R. N. (1995). Direct DNA extraction for PCR-mediated assays of soil organisms. Appl. Environ. Microbiol. 61, 39723976.

Weisman, W. H. (1998). Total petroleum hydrocarbon criteria working group: a risk-based approach for the management of total petroleum hydrocarbons in soil. Soil Sediment Contam. 7, 1-15. doi: 10.1080/10588339891 334168
Yamane, K., Maki, H., Nakayama, T., Nakajima, T., Nomura, N., Uchiyama, H., et al. (2008). Diversity and similarity of microbial communities in petroleum crude oils produced in Asia. Biosci. Biotechnol. Biochem. 72, 2831-2839. doi: $10.1271 / \mathrm{bbb} .80227$

Yang, S., Wen, X., Zhao, L., Shi, Y., and Jin, H. (2014). Crude oil treatment leads to shift of bacterial communities in soils from the deep active layer and upper permafrost along the China-Russia crude oil pipeline route. PLoS ONE 9:e96552. doi: 10.1371/journal.pone.0096552

Zhang, J., Lin, X., Liu, W., Wang, Y., Zeng, J., and Chen, H. (2012). Effect of organic wastes on the plant-microbe remediation for removal of aged PAHs in soils. J. Environ. Sci. (China) 24, 1476-1482. doi: 10.1016/S1001-0742(11)60951-0

Zhang, K., Hua, X.-F., Han, H.-L., Wang, J., Miao, C.-C., Xu, Y.-Y., et al. (2008). Enhanced bioaugmentation of petroleum- and saltcontaminated soil using wheat straw. Chemosphere 73, 1387-1392. doi: 10.1016/j.chemosphere.2008.08.040

Zhang, Q., Wang, D., Li, M., Xiang, W.-N., and Achal, V. (2014). Isolation and characterization of diesel degrading bacteria, Sphingomonas sp. and Acinetobacter junii from petroleum contaminated soil. Front. Earth Sci. 8:5863. doi: 10.1007/s11707-013-0415-6

Conflict of Interest Statement: The authors declare that the research was conducted in the absence of any commercial or financial relationships that could be construed as a potential conflict of interest.

Copyright (C) 2016 Al-Kindi and Abed. This is an open-access article distributed under the terms of the Creative Commons Attribution License (CC BY). The use, distribution or reproduction in other forums is permitted, provided the original author(s) or licensor are credited and that the original publication in this journal is cited, in accordance with accepted academic practice. No use, distribution or reproduction is permitted which does not comply with these terms. 


\section{APPENDIX}

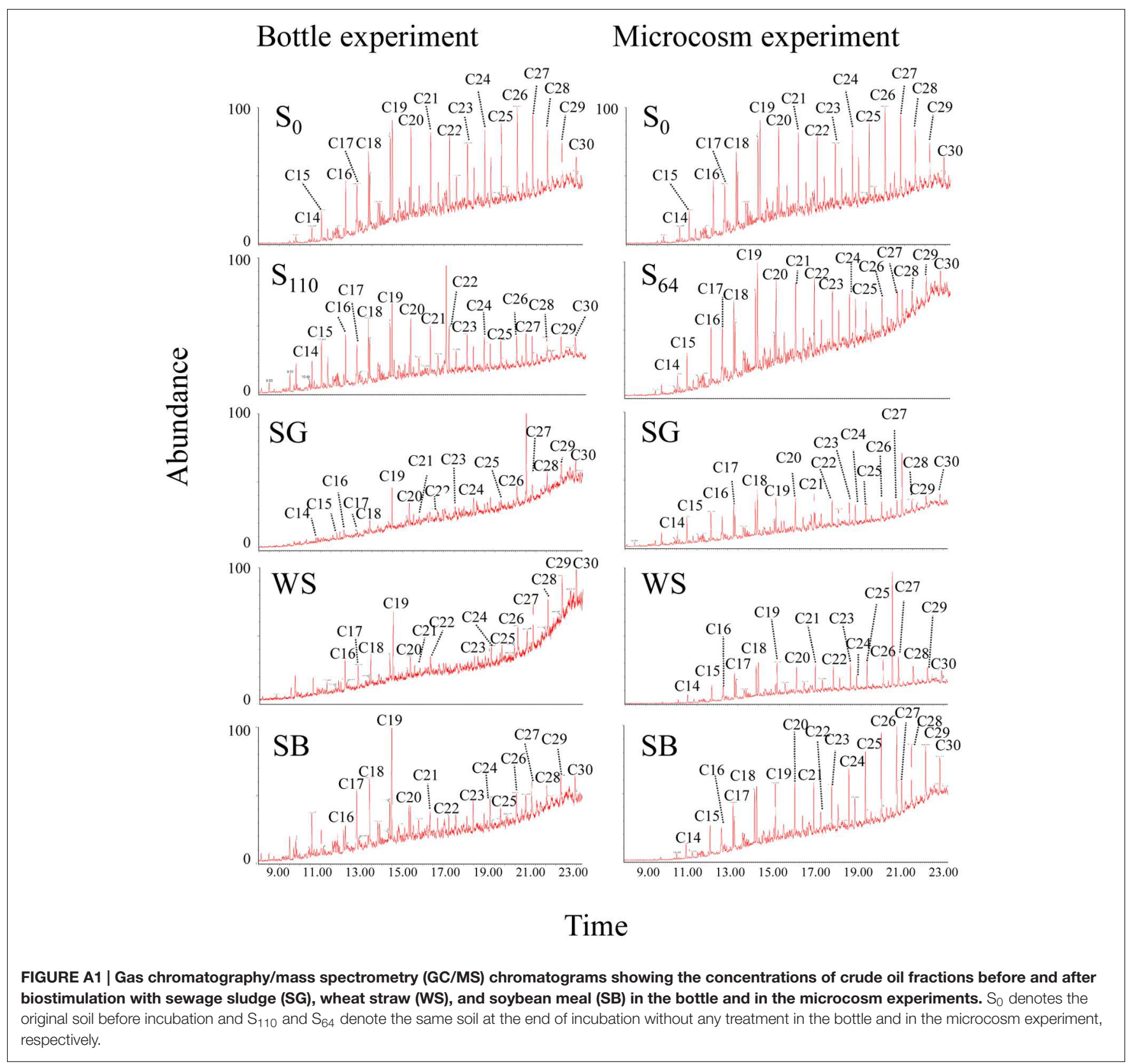

